unison with the sunspot periods, at all events enough to warrant further and more complete investigations being made on the point. I will not trespass on your valuable space further than to add a similar rough indication of the inverse relation that holds in the case of the summer rainfalls. They will be seen to be greatest in years of maximum sunspot.

In the following groups the rainfall of Dehra is taken for the months of June, July, August, September, and October during which the south-west mons'on rains fall. I give the separate rainfall during these months for each year, as well as the totals and averages.

\begin{tabular}{|c|c|c|c|c|c|}
\hline \multicolumn{3}{|c|}{ Maximum sun-spot groups. } & \multicolumn{3}{|c|}{ Minimum sun-spot groups. } \\
\hline Years. & Inches. & Tutals. & Years. & Inches. & Totals. \\
\hline $\begin{array}{l}186 \mathrm{I} \\
\mathrm{I} 862\end{array}$ & $\left.\begin{array}{l}9 r^{\prime} 4 \\
90.5\end{array}\right\}$ & I $8 I \cdot 9$ & $\begin{array}{l}1875 \\
\text { I } 876\end{array}$ & $\left.\begin{array}{l}67 \cdot 2 \\
76 \cdot 1\end{array}\right\}$ & $143^{\circ} 3$ \\
\hline \multicolumn{2}{|c|}{ Average for each year } & 90.9 & \multicolumn{3}{|c|}{ Average for each year 716} \\
\hline $\begin{array}{l}\text { I } 869 \\
\text { I } 870 \\
\text { I } 871\end{array}$ & $\left.\begin{array}{r}70 \cdot 5 \\
77 \cdot 2 \\
100 \cdot 2\end{array}\right\}$ & $247^{\circ} 9$ & $\begin{array}{l}\text { I } 865 \\
\text { I } 866 \\
\text { I } 867\end{array}$ & $\left.\begin{array}{l}58 \cdot 9 \\
67 \cdot 0 \\
60 \cdot 6\end{array}\right\}$ & $186 \cdot 5$ \\
\hline \multicolumn{2}{|c|}{ Average for each yea } & $82 \cdot 6$ & \multicolumn{3}{|c|}{ Average for each year $62 \cdot 1$} \\
\hline
\end{tabular}

The averages give a mean average excess in each year in the maximum sun-spot groups of 19.9 inches over each year in the minimum groups ; a givantic difference certainly, and apparently maintained pretty consistently throughout by the rainfall of each year. The defect in the winter rainfall of years of maximum sunspot and the corresponding excess in years of minimum sunspot together combine to render the excess in years of maximum sun-snot less apparent in the toral annual falls, though it still exists to a certain extcnt. The present year (at present abnormaily ieficient in solar activity) appears destined to fulfil the preceding relations to an alarming extent. The winter rainfall was unt:ually plentiful throughout Norchern India, while, up to the present time, when the monsoon should be in full swing, the rains, except in Eastern Bengal, have been so scanty that unless rain falls soon and abundantly, we shall have to face a farrine as fearful as that which is just now devastating Madras.

E. D. ARCHIBALD

\section{Greening of Oysters}

It has long been known that oysters, when removed from the sea and kept artificially in shallow pits filled with salt.water, assume a green colour which is or was much thought of by epicures. While this spring at Le Croisic, at the mouth of the Loire, my friend, Dr. Bornet, informed Prof. Lankester and myself that this singular change was particularly observable in the oyster preserves in the neighbourhood. He was at that time at a lo.s for an explanation, but I have just received a letter from him in which lie gives the solution of the problem, and this will I think be so interesting to many of the readers of NATURE, that I have ventured, although without his permission, to communicate it to them.

"As a souvenir of our meeting at Croisic, I send you some Corallinaceze from that locality. Several have not yet been detected on the English coast, where, however, they ought to occur. I have added a Diatom, Navicula fusiformis, Grunow, var. ostrearit. 'This species, whose contents are of a cobalt-blue colour during life, occurs in profusion in the oyster-preserves of Croisic, and it is because they feed on this Diatom that they become green. Nothing is easier than to demonstrate the fact by placing white oysters in a plate of sea-water containing nothing but Naziculli fusiformis, and the "greening" takes place in thirty-six hours. As often as the experiment is repeated, the same result follows. But why should Navicula fusiformis be blue, while all other Diatoms are culourless?"

W. T. Thiselton Dyer

P.S.-Since this note has been in type Prof. Oliver has called my attention to a paper in the "Mémoires de la Société Linncéene du Calvados," I\$24, pp. 135-158, by Benjamin Gaillon, "Sur la cause de la colcration des Huîtres et sur les Animalcules qui servent à leur nutrition." These animalcules form masses which he compares to the green matter of Priestley, and as he refers them to the genus Navicula of Bory, they are no doubt identical with those which Dr. Bornet has studied. Gaillon refers to an earlier memoir of his own on the same subject published by the Academy of Sciences of Rouen, and in the Annales des Sciences Physiques, for $182 \mathrm{I}$. W. T. T. D.

\section{Reproduction by Conjugation}

THE phenomenon to which Mr. Bennett alludes is, I presume, well known; but it is not universal, though common. He will fird illustrations in Hassall's "British Freshwater Algæ," where the zygospores aie formed in both filaments simultaneously; e.g., plate I9, Zygnema (Spirogyra); plate 38 , several species of Tyndaridea. But in those genera in which the Zygospore is formed between the filaments it would seem impossible to decide which is male and which is female, e.g., plate 39, Tyndaridea conspicua, immersa, Ralfsii, and decussata; or in the genera Mesocarpus, plates 42-47, and Stenocarpus, plates $47-49$.

\section{GEORGE HENSLOW}

\section{Strange Dream Phenomenon}

AFTER reading the interesting letter on a "Strange Dream Phenomenon" which appeared in NATURE (vol. xvi. p. 329) it occurred to me that it might be worth while to put on recurd the following experience which connects in a very striking manner the phenomena of dreaming and subjective vision. Sime time ago, when rather tired by overwork, I dreamt during the night that some one had entered my bedroom and was approaching the pillow under my head with the intention of abstracting some valuable papers which I fancied were concealed beneath it. I noticed in every particular the dress, stature, and features of the intending robber, but just as he put furward his hand towards the bed I began to awake, slowly at first, but with great celerity as soon as I perceived the figure of my dream walking slowly duwn the side of the bed; wide awake now, $I$ watched it reach the corner bedpust, turn round, and with. measured noiseless step pass along the foot, till on coming between the window and myself it disappeared, as all the "ghosts" with which I was then afflicted were wont to do when shone through by the light.

I did not sleep any more for the rest of the night, and hence arn perfectly certain that this was not "a drem within a dream," but a clear case of a subjective vision prolonged from the sleepng into the waking state, and thus affurding evidence to prove the essential identity which underlies the phenomena of "dream. ing dreams" and seeing "ghosts." W. J. S.

\section{OUR ASTRONOMTCAL COLUMN}

THE SATELlites OF MARs.-The Paris correspondent of the Times, writing on August 27, states that at the meeting of the Academy of Sciences the same day, M. Faye had announced the independent discovery of the satellites of Mars by M. Borrelly at Marseilles, clauming for him even an earlier detection than was effected at Washington. Prof. Watson's name being introduced as the American discoverer instead of that of Prof. Asaph Hall, it is clear that the statement has arisen from a misconception on the part of the reporter at the sitting of the Academy, who has confounded the discovery of No. 174 of the minor-planet group, by Watson and Borrelly, with that of the satellites of Mars.

A letter from Rear-Admiral Rodgers, Superintendent of the Naval Observatory, Washington, to the Secretary of the Navy, dated August 2 I, furnishes particulars of the observations and calculations bearing upon both satellites, which had been made up to that date. The outer satellite was remarked on the $I I t h$, but its true character was not certainly recognised until the 16th. On the following night Prof. Hall first observed the inner satellite. The discoveries were telegraphed to Messrs. Alvan Clark and Sons, at Cambridyeport, on the I8th, that confirmatory evidence of the existence of the satellites might be obtained by means of the 26 -inch telescope of Mr. McCormick, at present in the hands of those eminent opticians, who succeeded in verifying Prof. Hall's discovery, as did also Prof. Pickering and his assistants at Cambridge, Mass. On the Igth the discovery was 